\title{
Model Joint Business Group Based Knowledge for Fishermen Community Empowerment Strategies (Case Study of Business Diversification on Solid Capture Region Cirebon City)
}

\author{
Liliek Soeprijadi \\ Faculty of Fisheries and Marine Science, Brawijaya University, Indonesia \\ E-mail: lilieksoeprijadi@yahoo.com \\ Endang Yuli \\ Faculty of Fisheries and Marine Science, Brawijaya University, Indonesia \\ Edi Susilo \\ Faculty of Fisheries and Marine Science Brawijaya University, Indonesia \\ Rudianto \\ Faculty of Fisheries and Marine Science Brawijaya University, Indonesia
}

Received: March 7, 2013 Accepted: March 29, 2013 Published: April 5, 2013

doi: 10.5296/ bmh.v1i1.3485

URL: http://dx.doi.org/10.5296/ bmh.v1i1.3485

\begin{abstract}
The purpose of this study was to analyze the effect of public capital fishing, fish processing business and micro-business skills to the programs and activities of the agency joint venture (KUB) coastal fishing town of Cirebon: to analyze the effect of public capital fishing, fish processing business and micro-enterprise skills through the agency the joint venture (KUB) fisherman exchange coastal fishing town of Cirebon: to analyze the effect of public capital fishing, fish processing business and micro-enterprise skills through a joint venture group institutions (KUB) and exchange fishing to conservation of fish resources in the coastal city of Cirebon, and to formulate a model of the joint venture (KUB) knowledge as a strategy of empowerment of fishing communities in the city of Cirebon. Analysis of regression weights measurement models with business groups (KUB) based knowledge as a fishing community empowerment strategy was as follows: capital fishing communities and micro-enterprise skills significantly influence the institutional joint venture (KUB) Cirebon fishermen. While
\end{abstract}


the fish processing business variables didn't significantly influence the institutional joint venture (KUB) Cirebon fishermen; stock fishing communities, fish processing business and micro-enterprise skills together through the institution of the joint venture (KUB) fisherman significant effect on the value of rate of coastal fishing town of Cirebon. While the partial correlation between public capital fishing, fish processing business and micro-enterprise skills exchange coastal fishing town of Cirebon was not significant; stock fishing communities, fish processing business and micro-enterprise skills together through the institution of the joint venture (KUB) and exchange rates have a significant effect fishing conservation of coastal fish resources Cirebon. While the partial correlation between public capital fishing, fish processing business and micro-business skills for the preservation of coastal fishery resources Cirebon was not significant, and KUB institutional model based knowledge capital in the form of fishing communities, fish processing business and micro-enterprise skills through a strategy of empowerment fishing communities significantly influence conservation of fish resources in coastal city of Cirebon.

Keywords: KUB based knowledge, empowerment strategies, diversification of fishing effort 


\section{Introduction}

Development of fisheries sector in Indonesia was expected to contribute to the five important components of national development goals, namely: (1) economic growth (pro-growth), (2) expansion of employment (pro job), (3) reduction of poverty (pro poor), (4) pro-environment, and (5) mainstream (pro gender). However, until now the development of fishery resources has not shown a significant economic contribution to national development (Yafiz et al., 2009). Based on reports CBS (2011) Gross Domestic Product (GDP) more fishing than agriculture, due growth in 2007-2010 reached 27.3 percent/year. In the third quarter of 2011, the contribution of fisheries to GDP reached 19.85 percent agricultural groups or second ranks after food. Meanwhile, the increase in fisheries production has increased significantly, which in 2009 amounted to 5.1 million tons to 5.3 million tons in 2010 . For the record exports in 2009 amounted to 2.48 billion dollars, and in 2010 to 2.8 billion dollars, and soared in 2011 amounted to 3.2 billion dollars. Then in 2011 to 5.4 million tons or an increase of about 1.79 percent and the achievement of export value in the period 2007 to 2011 have increased on average higher, at 9.72 percent/year.

Major fishery contributed to national economic growth, it appeared not to alter the level of welfare of the fishing communities that produce the fishery. According to the Central Statistics Agency (BPS) in 2008 mentioned, too, that the poor in Indonesia reached 34.96 million people and $63.47 \%$ of them are people who live in coastal region. While Mubyarto et al. (1984), said most of the fishermen were the ones being poor, poor, and very poor. Poverty is related to the fishing stock condition of fishery resources, the quality of human resources, infrastructure facilities services access to capital, technology and markets (Dahuri, 2008).

Fisheries resources were a promising potential in supporting the community's economy, especially for fishermen. On the other hand, the logical consequence of the utilization of fishery resources as common property resources (common property) and is open to the public (open access), the utilization of fishery resources these days tend to exceed the carrying capacity of the resource (over exploitation) (Stanis et al, 2007). It was recognized that not all people have the ability fishermen optimal utilization of marine resources due to constraints on fishing locations were solid, fish stocks began to decrease and it was seasonal, the acquisition of knowledge and technology in the field of fisheries and marine resource potential was varied, which not all waters have the potential catch. Therefore fishermen in each coastal region has a different character in the utilization of coastal areas, making it less threat of environmental damage and fish resources be serious. The potential of fish resources were depleted, the density and the ability of fishermen fishing locations that vary due to obstacles of knowledge and advancement of technology, it was necessary to look for other alternatives in the use of coastal areas, so the utilization of coastal areas can be done optimally to improve the welfare and preservation of the coastal environment (Haque et al., 1998).

Diversification of business for a few families of fishermen in coastal areas need to be implemented, so the fishing community efforts were not only focused on fishing effort, but also can be directed at other businesses outside the field of arrests. Diversification efforts 
were expected to provide the opportunity of fishing communities, to increase their income when not to fish because there were other sources of income to sustain their lives. Kusnadi (2002), explained that the decision to diversify the work was an effort and rational choice would be more beneficial interest in ensuring household survival and improve quality of life. Diversifying the job will be given the flexibility and freedom to the fishermen to earn income from a variety of sources and employment opportunities, in the context of diversification, activity remains fishery be used as one source of revenue that can be utilized at the right time.

Problems in solid fishery fishing waters that were found in the city of Cirebon can be seen in aspects of poverty, reduction in fish production, net gear that can damage the environment, the number of fishing vessel owners from year to year has decreased, the amount of fishing gear used also declined, utilization fish resources in coastal waters of Cirebon city trended down from year to year, the occurrence of overfishing, pollution and human resources were low.

Problems utilization of fish resources in the coastal waters of Cirebon city trended down from year to year, due to high exploitation in the area of dense water fishing gear, most of the fishermen catching fish in sea water ranges in the Java Sea, such as the north coast of Cirebon, so overfishing occurs. Factors causing overfishing was the volume of fish catch has declined, the size of the fish were caught fishing grounds getting smaller and further away from the beach so it take longer. This resulted in increasing the cost of going to sea, and at the same time tends to decrease the income of fishermen. Besides the rate of catching fish resources in excess of potential production of sustainable. This condition was the cause or the most dominant form of poverty fishermen were natural factors (Abdullah, 1993).

Fishing community empowerment approach was a solution to overcome the problem of poverty. Bangladesh rural development expert explained that empowerment refers to the word "empowerment", which means the process was to develop the ability to empower people to eventually be self-sustaining community. Further Haque argues that community development is a collective action that affects individual welfare, so that the meaning was to empower individuals to build a society capable of independent and able to solve their own problems. Poverty fishing was a complex phenomenon that was difficult simply explained by one factor alone, making diversification a variety of activities in fishing communities to provide added value to the welfare of fishermen and resource sustainability course fish can still be maintained. Mukehhrjee et al. (2001) explained that the fishermen actually have assets held for life, so that he could live his life properly. Further explained or capital assets include human capital, natural resources, capital, economic capital, physical capital and social capital.

Based on some of the problems mentioned above, it was necessary to research on community empowerment strategy through diversification approach fisherman catching a dense region. Diversification of fishing effort was diversifying business activities other than fishing by fishermen and or family as alternative livelihood development efforts. Meanwhile, alternative livelihoods were a new business or economic activity are being developed to reduce or eliminate pressure on fish resources, as well as to increase the income of a fishermen family. 


\section{Materials and Methods}

Fishermen worse off welfare level, two-factor, were: (1) natural factors associated with fluctuations in the fish, (2) non-natural factors, that factors associated with lameness in institutions for the results, the absence of social security crew, and network marketing of fish that was vulnerable to price fluctuations, limited fish processing technology, the negative impact of modernization, and the limited employment opportunities that can be accessed by the fishing community (Kusnadi, 2000).

The study was conducted in 27 villages in three districts of coastal Mundu and Cirebon District, coastal of Cirebon city. The respondents sample was representative of proportional each coastal community, while the fishermen were divided into several strata, for example, the strata fishing gear, fishing aquaculture, commercial fisherman, fishing skipper fish, fish processing. In the present study used a sample size of 124 respondents. In this study collected two types of data, namely primary data and secondary data. Primary data was collected through interviews and direct observation to respondents. Secondary data was sourced from the department of marine and fisheries Cirebon city, village offices, district offices in the form of literature, studies and reports. Data collection method: to obtain the data used several methods of data collection as follows: (1) the interview: that the data collection techniques by conducting interviews with informants researchers to obtain the required data, (2) documentation: the data obtained in the form of notes field, reports, statistics and monographs. The research instruments to obtain the data in this study make use of questionnaires.

Analysis of data will theoretically analyzed the relationship between the variables to prove the hypothesis that had been developed to find the most appropriate model in explaining the relationship capital of fishing communities, fish processing business and micro-enterprise skills, through an institutional approach coastal areas Cirebon fishermen contribute to the exchange rate and conservation of fishery resources. With these considerations, use the statistical technique to analyze the results of SEM (structural equation modeling). Base on the theoretical basis drawn diagram path in Figure 1. SEM (structural equation modeling) using only input data matrix variance or covariance or correlation matrix. The raw data observations incorporated into the program AMOS 4.01., AMOS will further transform the raw data into a matrix of covariance or correlation matrix. To test the overall model of the relationship capital of fishing communities, fish processing business and micro-business skills, through an institutional approach coastal area that contribute to the exchange of fishermen and conservation of fishery resources Cirebon. The best results of the test the overall relationship between some of these variables in doing SWOT test, to see the strengths and weaknesses of fishermen development.

\section{Results and Discussion}

After analyzing measurement model through confirmatory factor analysis and see that each indicator can be used to define a latent construct, then a full SEM models can be analyzed. Analysis of the data processing stage full SEM models was done by testing the suitability and the test statistic. The results of processing data for a full analysis of SEM models show in 


\section{Macrothink}

Business and Management Horizons

ISSN 2326-0297

2013, Vol. 1, No. 1

Figure 2. Suitability indices as the model used in the confirmatory factor analysis. SEM model testing was intended to look at the suitability of the model. The results of treatment were presented in Table 1.

The results of Table 1 . showed chi square a large $(965.292>381.873)$ and a probability value below 0.05 was equal to 0.000 . In addition, the value of GFI $(0.744<0.9)$, AGFI $(0.693<0.9)$, CMIN/DF $(2.856>2.00)$ and RMSEA $(0.102>0.08)$ did not meet the requirements. However, TLI $(0.832<0.95)$ and CFI $(0.849<0.95)$ were included in the marginal fit. Thus, it can be concluded that the model developed did not meet the eligibility requirements necessary to modify the model so that the model in Figure 3. This is in accordance with the opinion of Ferdinand (2005), that the confirmatory factor analysis. Structural Equation Model testing on modeling studies were also performed with two kinds of test, the suitability model and the significance test of causality through regression coefficient test. Suitability indices as the model used in the confirmatory factor analysis. SEM model testing was intended to look at the suitability of the model. The results of treatment were presented in following Table 2.

Table 1. The result of feasibility testing model on full model

\begin{tabular}{|l|l|l|l|}
\hline Goodness of Fit Index & Cut off Value & Result & $\begin{array}{l}\text { Evaluation } \\
\text { Model }\end{array}$ \\
\hline Chi-Square & $\begin{array}{l}\leq 381,873\left(\chi_{\text {tabel }}^{2} \text { with } \mathrm{db}:\right. \\
338 \text { and p:5\%) }\end{array}$ & 965.292 & Not Good \\
\hline Probability & $\geq 0.05$ & 0.000 & Not Good \\
\hline RMSEA & $\leq 0.08$ & 0.102 & Not Good \\
\hline GFI & $\geq 0.90$ & 0.744 & Not Good \\
\hline AGFI & $\geq 0.90$ & 0.693 & Not Good \\
\hline CMIN/DF & $\leq 2.00$ & 2.856 & Not Good \\
\hline TLI & $\geq 0.95$ & 0.832 & Marginal \\
\hline CFI & $\geq 0.95$ & 0.849 & Marginal \\
\hline
\end{tabular}

Resource: Primary data processed (2012) 


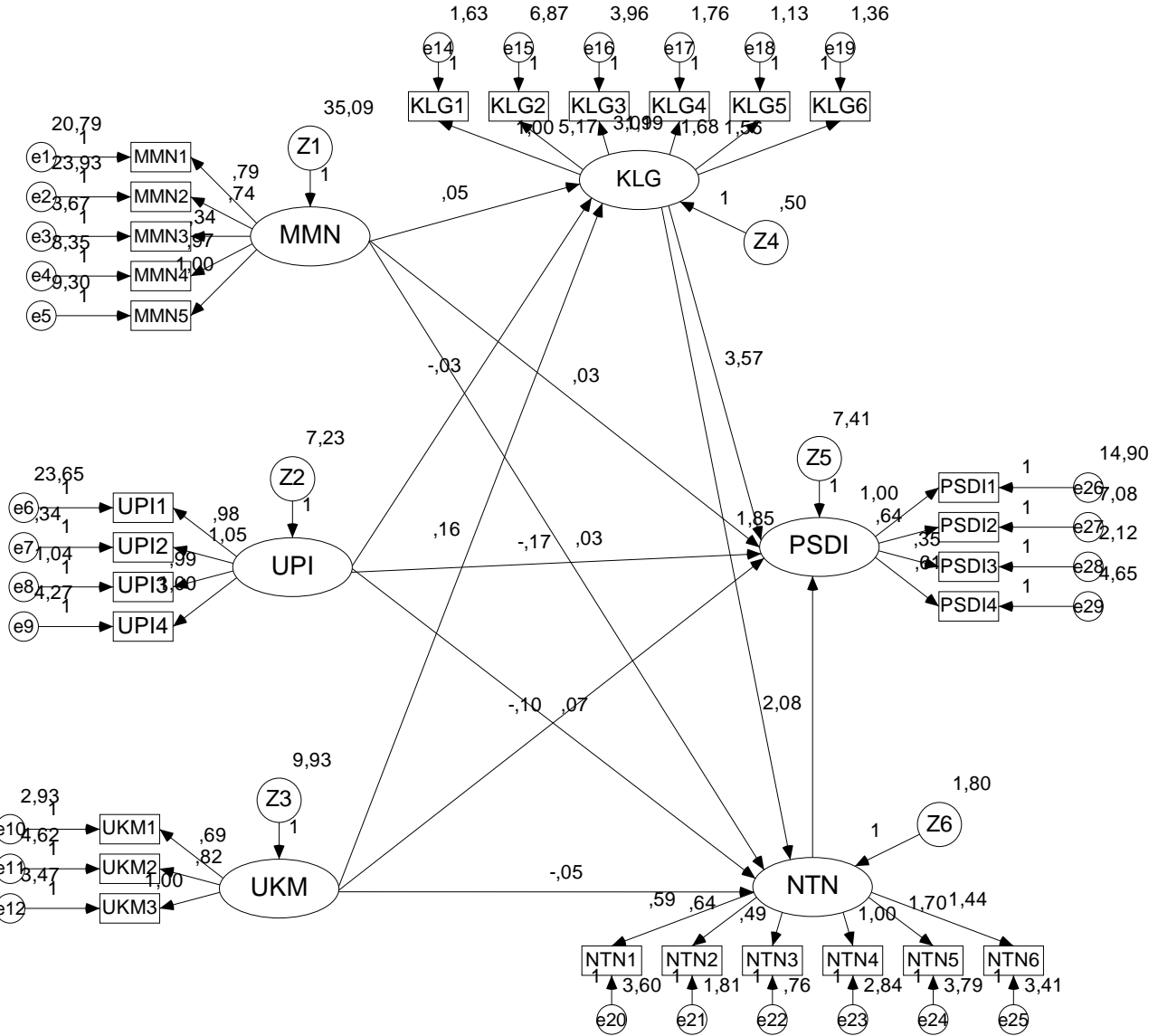

Figure 2. Full analysis model before modification

Table 2. The result of feasibility testing model on full model

\begin{tabular}{|l|l|l|l|}
\hline Goodness of Fit Index & Cut off Value & Result & $\begin{array}{l}\text { Evaluation } \\
\text { Model }\end{array}$ \\
\hline Chi-Square & $\begin{array}{l}\leq 363,783\left(\chi_{\text {tabel }}^{2} \text { with db: }\right. \\
321 \text { and p: } 5 \%)\end{array}$ & 659.146 & Not Good \\
\hline Probability & $\geq 0.05$ & 0.000 & Not Good \\
\hline RMSEA & $\leq 0.08$ & 0.077 & Good \\
\hline GFI & $\geq 0.90$ & 0.814 & Marginal \\
\hline AGFI & $\geq 0.90$ & 0.764 & Not Good \\
\hline CMIN/DF & $\leq 2.00$ & 2.053 & Not Good \\
\hline TLI & $\geq 0.95$ & 0.904 & Marginal \\
\hline CFI & $\geq 0.95$ & 0.919 & Marginal \\
\hline
\end{tabular}

Resource: Primary data processed (2012) 


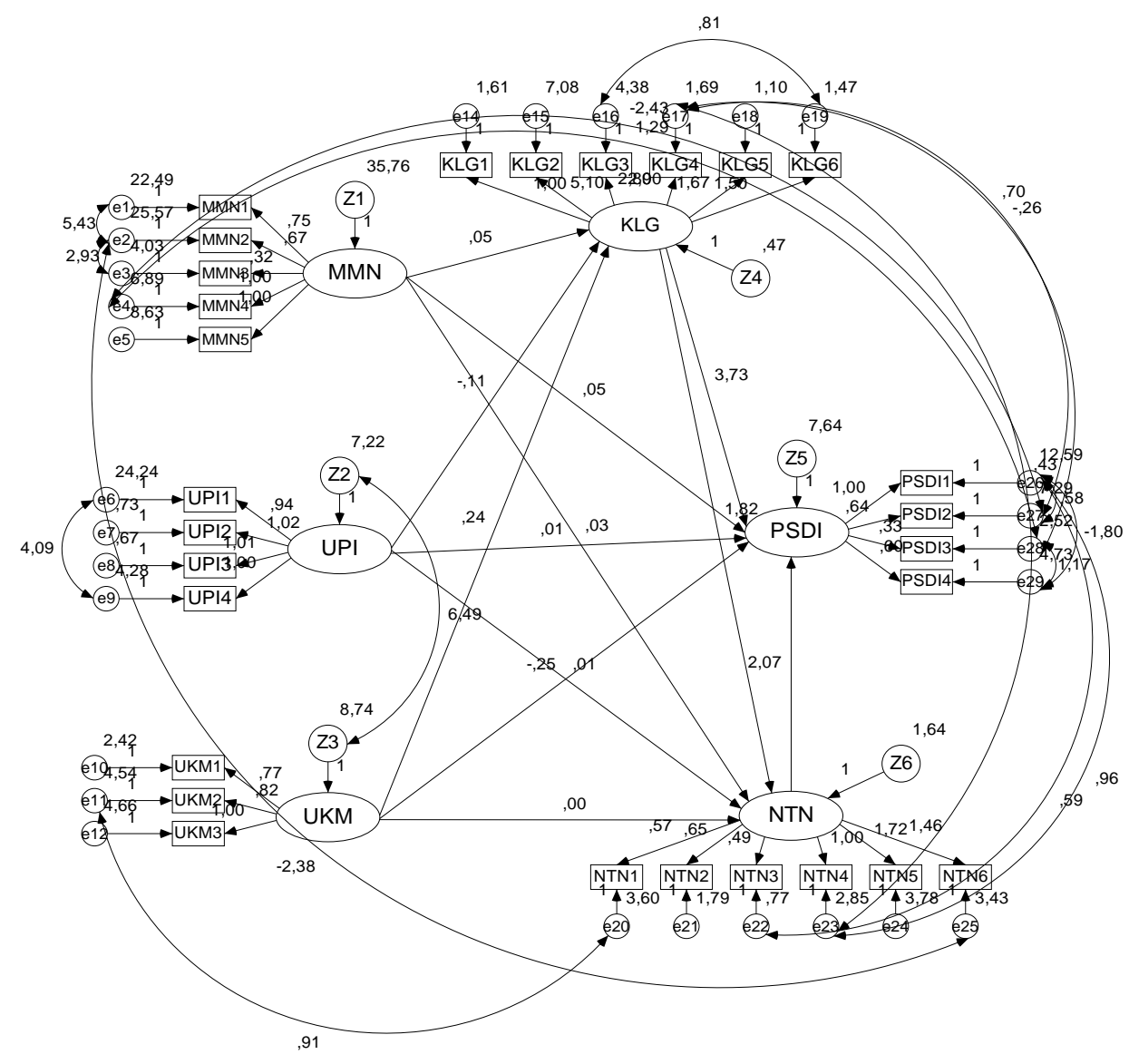

Figure 3. Full analysis model after modification

The results of Table 2 . showed chi square a large $(659.146>363.783)$ and a probability value below 0.05 is equal to 0.000 . However, the value of GFI $(0.8<0.814<0.9)$, TLI $(0.8<0.904$ $<0.95)$, CFI $(0.8<0.919<0.95)$, and RMSEA $(0.077<0.08)$ was compliant so it can be said that the model used in accordance with the data. After conducting an assessment of the assumptions that exist in the SEM, will further hypothesis testing. Testing four hypotheses proposed in this study was based on the value of Critical Ratio (CR) of a causal relationship.

Explanation of Figure 4. above provide that information to the fishermen community empowerment strategy through diversification of activities in the territories captured in the of Cirebon city solid was the institutional aspects of coastal areas. Institutional aspects were being the key word for successful diversification. To create a strong institutional coastal areas, the capital aspect of the society, the business aspects of the micro skills and aspects of fish processing business into a major input institutional coastal areas. The institution has a significant relationship with the fishermen exchange (NTN) as an indicator of the welfare of fishermen. The institution has a significant relationship with the conservation of fish resources. Given the results of SEM analysis generating institutional empowerment as a strategy of intensive fishing territory captured in the city of Cirebon, we then need to do a SWOT analysis of the institutional aspects of coastal areas. 


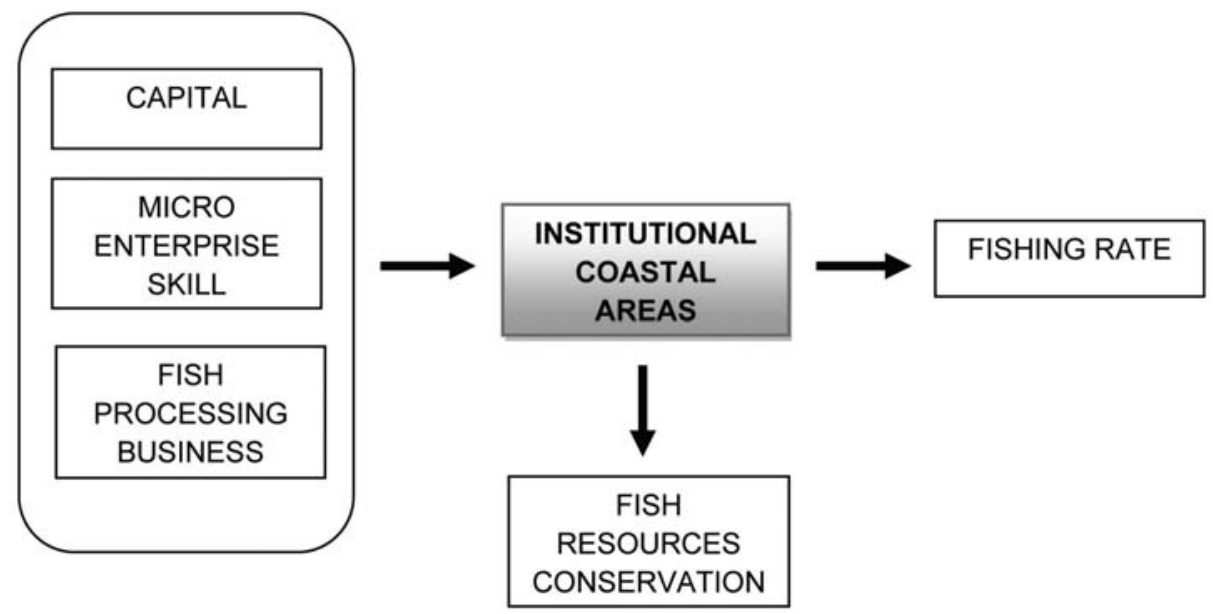

Figure 4. Significant relationship between the elements of the institutional diversification efforts between the coastal areas and coastal areas with NTN institutional and conservation of fish resources

\section{SWOT Analysis}

For the fishing community empowerment strategy through diversification in the fishing town of Cirebon solid, note the external factors and internal institutions to realize a steady in coastal areas. Institutions can be defined into two parts: first, as the institute was institutional, agency/organization incorporated for managing activities and second, the institutionalization of values or institutionalized. (Dahuri et al., 2008). Institutional coastal areas in this study include three (3) aspects: institution as an organization. In this regard there were three aspects that were developed, namely: first, an increase in the ability of the personnel who work instituted, and mobilize the energy to work instituted, both providing office facilities, equipment and materials as well as other facilities to operate the institution, and the third was the provision of funds operations and maintenance and Development to finance the institution. SWOT Analysis first created the internal conditions and external analysis using Internal Factors Analysis Summary (IFAS) and External Factors Analysis Summary (EFAS). Assessment method was based on the importance of an attribute/indicator and the influence of these attributes on other attributes within a factor (Marimin, et al., 2010). The assessment process carried out by the following steps:

1) Grouping the factors into four factors: strengths, weaknesses, opportunities and threats.

Grouping attributes into the strength and weaknesses based on the value or status of the current state, which has a status attribute bad to optimal status/ weakness factors go poorly, whereas attributes to optimal status/to highly optimized well/very well come into force attributes ;

2) Assessment of the attributes on each factor based on importance values (weights), influence (rating). Important values ranged from 0 (not important) to 100 (very 
important). While the value of influence or rating ranging from 1 (no impact) to 5 (very

influential). Do calculation scores by multiplying the critical value/weight in

influence/rating.

3) The attributes with the highest scores were the key attributes of a factor.

\section{Joint Business Group (KUB)}

KUB in Cirebon City that studied were 9 KUBs. 9 KUBs was a target of the study given the results of SEM analysis showed that the institutions in coastal areas key to successful community development programs through diversification. Joint Business Group (KUB) fishing was a non-legal entity or that have been incorporated in the form of a group formed by the fishermen by the agreement / consensus all members who are guided by a shared desire to strive together and collectively accountable to raise revenues member. KUB formation can be done on the basis of similarity of business and multi-faceted nature of inter-related and need to be pursued as far as possible to accommodate the interests of KUB's member. In this research government institution (SKPD) which handles KUB not be the target, because the actual spearhead community empowerment was KUB.

Table 3. Identify key performance inhibitors strength

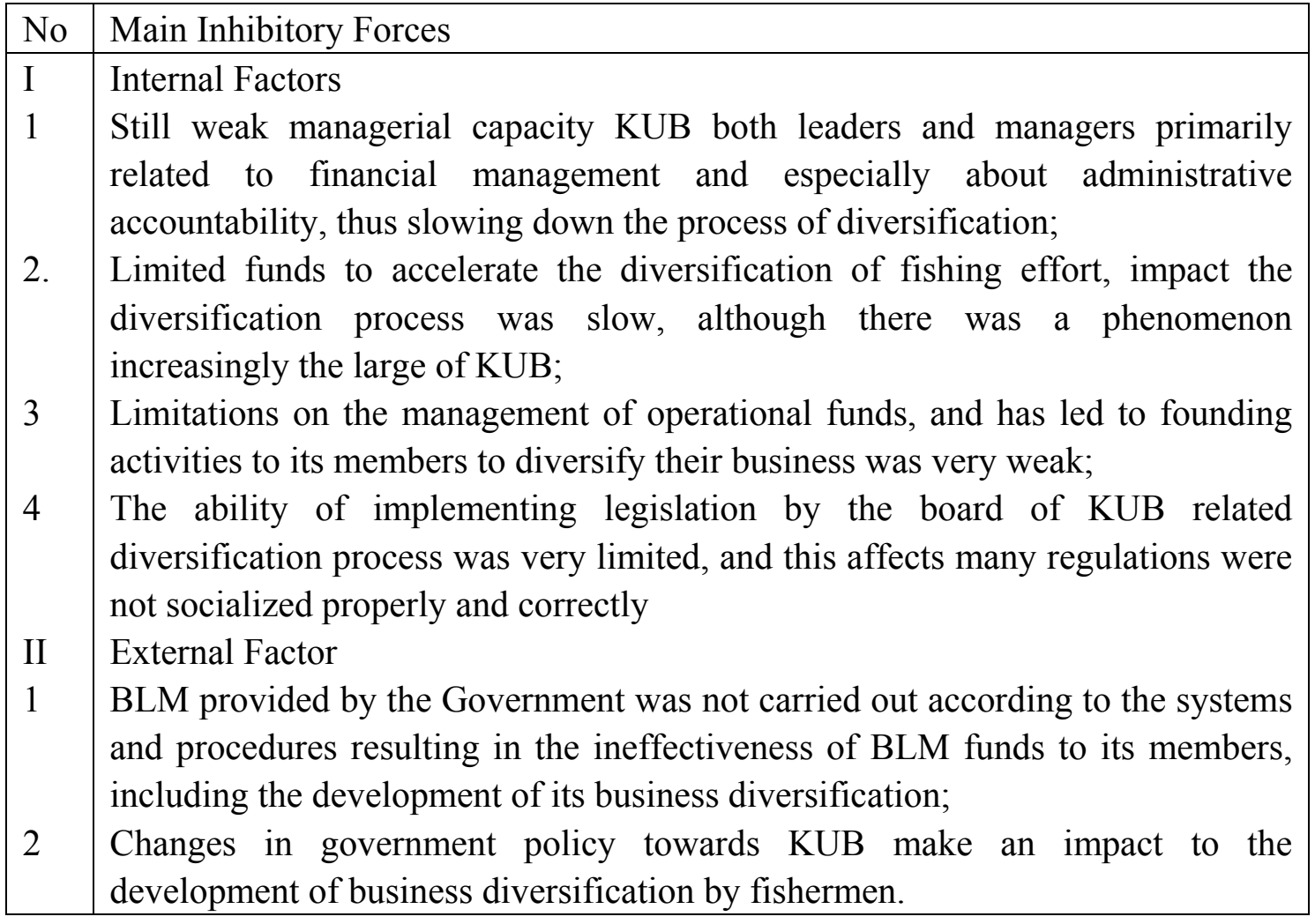

Resource: Primary data processed (2012)

Based on Table 3 above, then arrange on the power constraint, the relative impact and ease of solution Table 4. 
Table 4. Strength inhibitor, relative impact and ease solution

\begin{tabular}{|l|l|l|l|}
\hline No & Strength Retarder & Relative impact & Ease trouble shooting \\
\hline 1. & $\begin{array}{l}\text { Internal Factors } \\
\text { Weak capacity of } \\
\text { managerial in KUB; } \\
\text { Limited funds quickly treat } \\
\text { the process of } \\
\text { diversification; }\end{array}$ & 5 & 3 \\
3. & $\begin{array}{l}\text { Limitations of the } \\
\text { operational management of } \\
\text { KUB and devices }\end{array}$ & 3 & 1 \\
4. & $\begin{array}{l}\text { Implementing rules and } \\
\text { regulations } \\
\text { External Factors }\end{array}$ & 3 & 2 \\
II. & $\begin{array}{l}\text { Implementation BLM } \\
\text { improper procedures; } \\
\text { KUB policy changes }\end{array}$ & 3 & 3 \\
6. & 5 & 1 \\
\hline
\end{tabular}

Resource: Primary data processed (2012)

Relative Impact Scale: $\quad$ Easy Solving Scale

1: Very Less 1: Difficult

2: Less 2: Less Difficult

3: Enough 3: It's hard enough

4: Strong 4: easy

5: It is strongly inhibits 5 : Very easy

The next stage was to generate a driving force for the success of KUB in promoting welfare of fishermen, namely:

(1) There was a driving force that can help KUB improve their performance goals; Sign the driving forces that would help KUB achieve goals;

(2) Select the driving forces, the estimated positive possibilities that can help KUB improve performance;

(3) Required power analysis of the main driving forces. 
Table 5. List the driving force

\begin{tabular}{|l|l|}
\hline No & KUB Driving Force \\
\hline I & 3 (three) Intern Power \\
1. & Capacity Managerial from Administrator and Leader of KUB; \\
2. & KUB availability of operational funds to conduct training; \\
3. & Sense of togetherness between the officers and members of KUB \\
II & 3 (three) Ekstern Power \\
1. & Sustainable fostering the KUB by the Government; \\
2. & BLM to KUB proportionally (according to feasibility); \\
3. & KUB partnerships with investors \\
\hline
\end{tabular}

Sources: Primary data processed (2012)

The next step to create a table the driving force and the relative impact of control, to determine the relative impact and the degree of control the driving force KUB with the following steps:

(1) The driving force relative impact on the achievement of KUB;

(2) The relative impact was very strong and there was even less encouraging KUB;

There was an effort to supervise the management of KUB attached to the driving force;

(3) There was a driving force which is entirely under the control of KUB;

(4) There was also a driving force that was beyond the control or influence and KUB;

(5) There SKPD of Cirebon city who has control or influence over the forces driving KUB;

(6) Provision of weights for each of the driving force of the impact and influence of KUB.

Table 6. Driving force, relative impact and full Government

\begin{tabular}{|c|c|c|c|c|}
\hline No & Driving Force & $\begin{array}{l}\text { Relative } \\
\text { Impact }\end{array}$ & Under Control & $\begin{array}{l}\text { Out of } \\
\text { Control KUB } \\
\text { Institutions }\end{array}$ \\
\hline I. & 3 (three) Intern Power & & & \\
\hline 1. & $\begin{array}{l}\text { Managerial skills of Chief and } \\
\text { Executive in KUB; }\end{array}$ & 5 & 4 & 4 \\
\hline 2. & $\begin{array}{l}\text { Availability of operational funds to } \\
\text { undertake development KUB built; }\end{array}$ & 4 & 3 & 4 \\
\hline $\begin{array}{l}3 . \\
\text { II. }\end{array}$ & $\begin{array}{l}\text { Sense of togetherness between the } \\
\text { officers and members of KUB } \\
\mathbf{3} \text { (three) External Power }\end{array}$ & 4 & 4 & 4 \\
\hline
\end{tabular}




\begin{tabular}{|c|c|c|c|c|}
\hline 1. & Fostering KUB sustainability by the & 3 & 4 & 5 \\
\hline 2 & Government; & 5 & 4 & 4 \\
\hline 3. & $\begin{array}{l}\text { (according to feasibility); } \\
\text { KUB partnerships with investors }\end{array}$ & 4 & 4 & 4 \\
\hline
\end{tabular}

Sources: Primary data processed (2012)

Relative impact Scale:

Scale under Control

1: Very Less

1: Hard controlled

2: Less encouraging

2: Less difficult to control

3: Simply push

3: Pretty hard

4: Strong push

4: Easily controlled

5: Very strong drive

5: Very easy

The next stage was to make the table associated with the relative levels of the driving forces and barriers to estimate the relative strength (strength) drivers and inhibitors:

(1) The performance of the current as the output of two mutually counteracting forces against each other to achieve a level of balance;

(2) Required level power analysis for weighting the relative strength (strength) drivers and inhibitors;

(3) Analyze and determine the value of the level of force that must refer to the values that have been done before;

There was power (force) which has a relative strength (Strength) was very strong and there were very weak. 


\section{Macrothink}

Business and Management Horizons

ISSN 2326-0297

2013, Vol. 1, No. 1

Table 7. Relative power level drivers and inhibitors

\begin{tabular}{|c|c|c|c|c|c|}
\hline No & Driving Force (force) & $\begin{array}{l}\text { Rate of relative } \\
\text { strength } \\
\text { (strength) }\end{array}$ & No & Strength retarder (force) & $\begin{array}{l}\text { Rate of relative } \\
\text { strength } \\
\text { (strength) }\end{array}$ \\
\hline 1. & 3 (three) Intern Power & & 1. & Internal Factors & \\
\hline 1. & $\begin{array}{l}\text { Managerial skill of KUB's } \\
\text { Leaders and Board; }\end{array}$ & 5 & 1. & $\begin{array}{l}\text { Weak of managerial } \\
\text { capacity of KUB; }\end{array}$ & 3 \\
\hline 2. & $\begin{array}{l}\text { Availability of operational } \\
\text { funds to undertake } \\
\text { development KUB built; }\end{array}$ & 4 & 2. & $\begin{array}{l}\text { Limited funds quickly } \\
\text { treat the process of } \\
\text { diversification; }\end{array}$ & 5 \\
\hline 3. & $\begin{array}{l}\text { Sense of togetherness } \\
\text { between the officers and } \\
\text { members of KUB }\end{array}$ & 4 & 3. & $\begin{array}{l}\text { Limitations of the } \\
\text { operational management } \\
\text { and devices of KUB }\end{array}$ & 3 \\
\hline 11 . & 3 (three) External Power & & 4. & Implementation of & 3 \\
\hline 1. & Fostering KUB & 3 & & legislation. & \\
\hline & sustainability by the & & 11. & External Factors & \\
\hline & $\begin{array}{l}\text { Government; } \\
\text { BLM to KUB }\end{array}$ & & 1. & $\begin{array}{l}\text { Implementation BLM } \\
\text { improper procedures; }\end{array}$ & 3 \\
\hline & $\begin{array}{l}\text { proportionally (according to } \\
\text { feasibility); } \\
\text { KUB partnerships with } \\
\text { investors }\end{array}$ & & 2. & KUB policy changes & 5 \\
\hline
\end{tabular}

Sources: Primary data processed (2012)

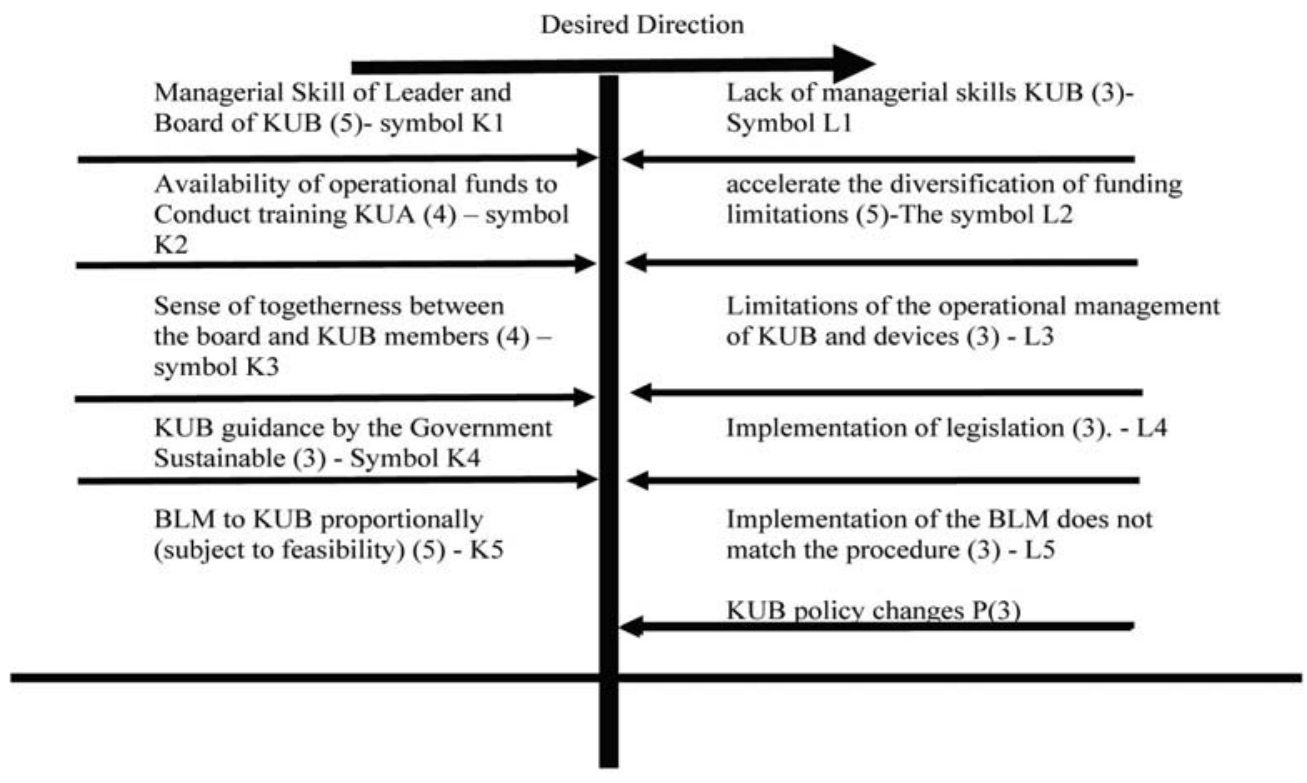

Figure 5. Diagram of the force field 
Based on Figure 5., then necessary to linkages between organized forces following steps:

(1) To examine the relationship between the amount power can be used the cross-impact matrix (cross-impact matrix);

(2) Everyone has the power to connect another;

(3) Give the value of the relationship between the driving force and the driving: Drivers and barriers, and the barriers and obstacles;

(4) Through the cross-impact matrices can be determined by adding up the value of linkage linkage by adding up the value of all the forces.

\section{Conclusion}

(1) Capital fishing communities and micro-enterprise skills significantly influence the institutional joint venture (KUB) Cirebon fishermen. While the fish processing business variables did not significantly influence the institutional joint venture (KUB) Cirebon fishermen.

(2) Capital fishing communities, fish processing business and micro-enterprise skills together through the institution of the joint venture (KUB) fisherman significant effect on the exchange rate of the coastal fishing town of Cirebon. While the partial correlation between public capital fishing, fish processing business and micro-enterprise skills exchange coastal fishing town of Cirebon was not significant.

(3) Capital fishing communities, fish processing business and micro-enterprise skills together through the institution of the joint venture (KUB) and the exchange rate have a significant fishing to conservation of coastal fish resources Cirebon. While the partial correlation between public capital fishing, fish processing business and micro-business skills for the preservation of coastal fishery resources Cirebon was not significant.

(4) Model of institutional knowledge in the form of capital KUB fishing communities, fish processing businesses and micro-enterprises with skills as a fishing community empowerment strategies significantly influence the conservation of fish resources in the coastal city of Cirebon.

\section{Recommendation}

(1) Expected KUB models based knowledge can be applied by governments and KUB itself in order to generate added value for improving the welfare of fishing communities

(2) The government was expected to focus more on fostering the KUB as an organization that bases its development to science. Therefore, the government needs to prepare some software or hardware to perform strengthening institutional (institutional strengthening). 
(3) KUB Board needs to learn continuously to improve the performance of organizations, including the deepening of knowledge about coaching and supervision to preserve fish resources

(4) KUB should be able to make independent and community members. In a sense people are able to plan, implement and evaluate their own needs. Future government functions only as a facilitator only. The worldview of government should be changed to include: government encourages competitive products "One KUB, One Product", preparation of technical and operational guidelines that funds were "recovery", training to KUB about the welfare of fishing communities without harming the environment.

(5) The worldview of society must also change, which include: leadership and management of KUB should always be able to keep the stability of the organization. Chairman of KUB as the major, must be able to create a climate conducive to the creation of a good working environment. KUB should be changed to a more flexible agency procedures, focuses on the essentials, and more concerned with the achievement of the expectations of its members in the management of fish resources, and also to achieve prosperity through value TNT. KUB should be able to control the rules that have been given by the government to control and the achievement of its vision and values. KUB should be open in providing information to its members and the surrounding community KUB

\section{References}

Abdullah, A. (1993). Mangrove forest management. Jakarta: State ministry of environment statistics. Welfare statistics. Jakarta. CV. Gading Komunikatama.

Bambang, A. N, (2007). Coastal and marine resource management empowerment through local wisdom Lembata District East Nusa Tenggara Province. Journal of Coastal Marine Research, 69(2), 67-82.

Dahuri, R. (2004). Resource development strategy based marine and fisheries economic democracy. National seminar on "strategic development of fisheries and marine resources. Based economic democracy”, 30-64.

Dahuri, R. (2008). The Applicationof Carrying Capacity Concept For Sustainable Coastal Resources Development In Indonesia. Center for Coastal and Marine Resources Studies (CCMRS) Bogor Agricultural University (IPB).

Department of Fisheries and Marine. (2011). Marine Strategy Framwork Directivy. Republic of Cyprus, Department of Fisheries and Marine Research.

Ferdinand, A. (2006). Structural equation modelling (SEM) in management research. Diponogo Universitas Management Master Program. Publisher University Board Diponogoro. 


\section{Macrothink}

Business and Management Horizons

ISSN 2326-0297

2013, Vol. 1, No. 1

Haque, U. N., Mark, N., \& Mathieson, D. J. (1998). The relative importance of political and economic variables in creditworthiness ratings (pp. 1-13). IMF working paper.

Kusnadi, H. (2000). Intermediate Financial Accounting (Intermediate), Principles, Procedures and Methods (1st ed.). Universitas Barawijaya. Malang.

Kusnadi, M. A. (2002). Fishermen social conflict, poverty and scramble resources fisheries. LKIS Yogyakarta.

Marimin, D. F., Sri, M., Retno, A., Suharjito \& Syarif, H. (2010). Added Value and Performance Analyses of Edamame Soybean Supply Chain: A Case Study. Operations And Supply Chain Management, 3(3), 148-163.

Ministry of Marine Affairs and Fisheries. (2006). Ministry of Marine Affairs and Fisheries Republic of Indonesia. Research Center for Capture Fisheries.

Mubyarto, L., Soetrisno \& Dove, M. R. (1984). Fishermen and poverty economic studies anthropology in two coastal villages, Eagles, Jakarta.

Mukherjee, A., Mattias V. B., \& Bridget, R. (2008). Hydrogeochemical comparison and effects of overlapping redox zones on groundwater arsenic near the Western (Bhagirathi sub-basin, India) and Eastern (Meghna sub-basin, Bangladesh) margins of the Bengal Basin. $\begin{array}{llll}\text { Journal of Contaminant Hydrology, } & \text { 99, }\end{array}$ http://dx.doi.org/10.1016/j.jconhyd.2007.10.005

Statistics Cirebon. (2011). Cirebon in figures 2011. Statistics published Cirebon.

Yafiz, M., Fedi, M. A., Sondita, S., Soemakaryo, R. D., \& Monintja. (2009). Financial analysis of fishing enterprises in the fishermen's welfare improvement model Rokan Hilir in Riau Province. Journal of fisheries and maritime affairs. 14(1), 81-92.

\section{Copyright Disclaimer}

Copyright reserved by the author(s).

This article is an open-access article distributed under the terms and conditions of the Creative Commons Attribution license (http://creativecommons.org/licenses/by/3.0/). 